International Journal of Social Sciences and Humanities
Available online at http://sciencescholar.us/journal/index.php/ijssh
Vol. 1 No. 2, August 2017, pages: 10 19
e-ISSN: 2550-7001, p-ISSN: 2550-701X
http://dx.doi.org/10.21744/ijssh.v1i2.31

\title{
Renewable Energy Sources and Local Development
}

\author{
CrossMark \\ Maria Rodriguez Gamez ; Antonio Vazquez Perez ${ }^{\text {; }}$; Antonio Sarmiento Sera ; \\ Zoila Millet Ronquillo ${ }^{\mathrm{d}}$
}

Article history: Received 5 January 2017; Accepted in revised form 20 July 2017; Approved 3 August 2017; Available online 10 August 2017

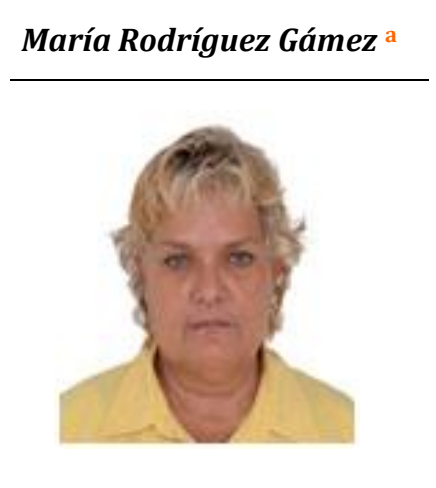

Keywords

Energy planning;

Geographical;

Information systems;

Renewable potentials;

Sustainable;

\begin{abstract}
Renewable sources are closely linked to the natural conditions of each region and locality, their availability is very varied from one site to another, being important the evaluation of the potential of these resources, in order to determine their best use under economically advantageous conditions. These constitute the equivalent fuel for the operation of the technologies that exploit them, their quantity, and quality; It also depends on the energy performance and reliability of the technology systems that employ them. An analysis of the importance of the determination of the regionalization of the RES is presented, showing the energy, economic and environmental impacts that can be estimated in specific regions and localities. For this, the studies carried out in the province of La Habana and in the municipality of San Luis in the province of Santiago de Cuba are presented as practical examples of a territorial planning, considering the conditions of each locality. The results are shown using the Geographic Information System (GIS). The contribution obtained allows the preliminary knowledge of the renewable potential (solar, wind, water and biomass), which can be considered for a regionalization of the planning with renewable energy sources, in order to reach the goals of sustainable development, based on the search of energy solutions at the Community level.
\end{abstract}

a Ph.D. Universidad Técnica de Manabí, FCMFQ, Portoviejo, Manabí (Ecuador/South América)

b Doctorate Program, Local development, Universidad Técnica de Manabí, FCMFQ, Portoviejo, Manabí Ecuador

c Ph.D. Universidad Tecnológica de la Habana (Cujae), CETER, La Habana, Cuba

d MsC. Empresa Eléctrica, Santiago de Cuba, Cuba 
e-ISSN : 2550-7001, p-ISSN : 2550-701X@ Copyright 2017. The Author. SS Journals Published by Universidad Técnica de Manabí.

This is an open-access article under the CC BY-SA 4.0 license

(https://creativecommons.org/licenses/by-sa/4.0/) All rights reserved.

\section{Contents}

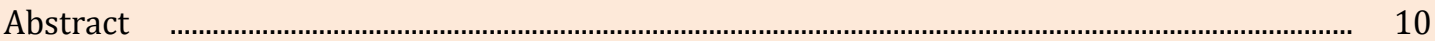

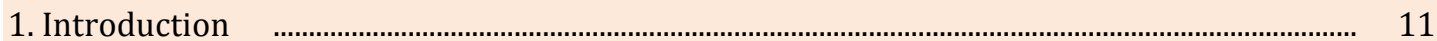

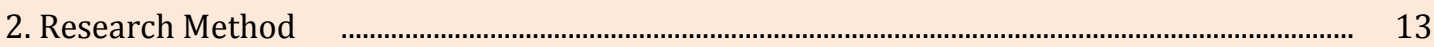

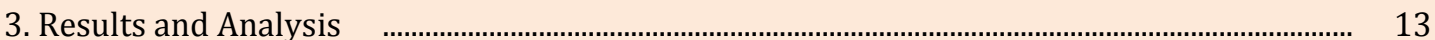

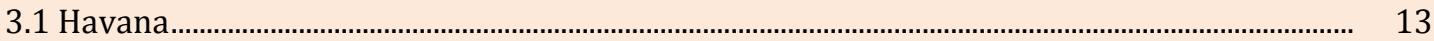

3.2 Evaluation of the incident solar potential in the province............................................................ 14

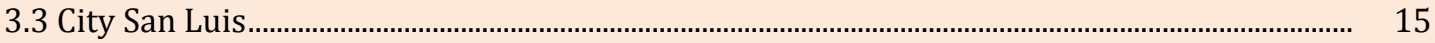

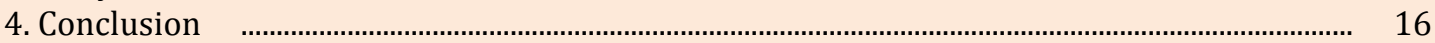

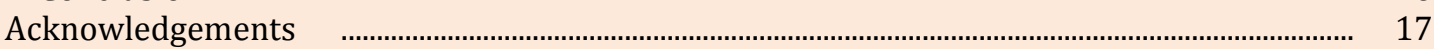

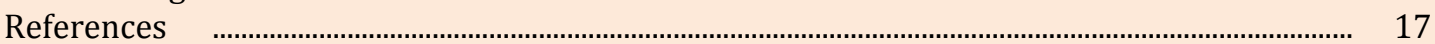

Biography of Authors $\quad$...................................................................................................................... 19

\section{Introduction}

De la misma forma que se trazan políticas regionales para resolver los problemas de investigación, desarrollo e innovación relacionados con el uso de recursos energéticos renovables en América Latina y El Caribe (ALC) [1], también se trabaja en función de disminuir los riesgos naturales, salvar la biodiversidad y mejorar las condiciones de vida de las comunidades que todavía no están conectadas a las redes eléctricas. En el plano nacional se requiere el trazado de estrategias que permitan la solución de problemas, de forma integral en regiones y zonas determinadas.

Las políticas trazadas por los países bajos, Alemania, Dinamarca, Australia, Japón, España y China, que han ido incorporando a su matriz energética un porciento importante de fuentes renovables de energía (FRE), han desarrollado proyectos de evaluación y estudios de potenciales renovables desde el nivel local, municipios, provincias y regiones, que le ha permitido determinar la zonificación del empleo más adecuado de estos recursos, considerando criterios de la calidad de los potenciales, en función de alcanzar una elevada eficiencia de la gestión energética, apostando por las garantías que puedan ofrecer las mejores condiciones de la disponibilidad del recurso, para asegurar una gestión económica viable y ventajosa.

En América del Norte existen programas de desarrollo de las FRE, Estados Unidos y Canadá proponen soluciones ventajosas. Ya se comenta la posibilidad de lograr en el uso de la penetración con fuentes renovables de energía a un $100 \%$ renovable [2]. Estos países proponen reducir las emisiones de gas de efecto invernadero utilizando el potencial de viento, agua y solar, mediante el suministro a partir de análisis de potenciales reales, además de proponer las tecnologías y el número de equipos que deben utilizarse. La proposición a pesar de ser costosa es realizable y se ha planteado que con el despliegue de una voluntad política responsabilizada con la sostenibilidad, sería posible lograr esos resultados.

Actualmente existen experiencias vinculadas con diferentes estudios para la regionalización de las FRE, pero de forma individual existen países que también trazan sus estrategias para la transición energética, un ejemplo de ello lo vemos plasmado en la propuesta que hace México, basada en un cambio de enfoque en el sector energético para alcanzar la transición, donde involucra el proceso a través del cual es posible disminuir las emisiones de gases de efecto invernadero, mitigar el impacto ambiental del sector y contribuir a combatir los efectos del cambio climático [3].

Gamez, M. R., Perez, A. V., Sera, A. S., \& Ronquillo, Z. M. (2017). Renewable energy sources and local development. International Journal of Social Sciences and Humanities, 1(2), 10-19.

https://doi.org/10.29332/ijssh.v1n2.31 
Argentina, Chile, Brasil y otros países latinoamericanos, han elaborado estrategias para la incorporación de las FRE a la matriz energética, cada uno con sus especificidades y características, han propuesto variantes de alternativas encaminadas a la explotación de sus mayores potenciales disponibles, vinculándolo a mitigar las emisiones contaminantes, reducir los impactos asociados a los combustibles fósiles y en dirección a la sostenibilidad energética. La aplicación de las FRE en zonas áridas [4], también es una forma de aprovechar el potencial renovable, en zonas que no son satisfactorias para el desarrollo de productos alimenticios, resultando una de las experiencias de interés vinculada con la regionalización de las FRE.

El impacto técnico más importante que ejercen los sistemas basados en FRE conectados a la red, está relacionado con la entrega de energía limpia para sustituir el consumo de combustibles fósiles; pero este aspecto que puede ser considerado como una de las ventajas derivadas del aprovechamiento de estos recursos, puede traducirse en complejos conflictos técnicos, cuando se la energía entregada se excede la tolerancia de penetración al sistema convencional. El efecto más relevante del estudio sobre la penetración de las renovables en la red, puede lograrse cuando se realiza de manera anticipada, permitiendo determinar los límites técnicos del aporte de energía, así como las inversiones que se requieren para asegurar la compatibilidad de ambas tecnologías en un mismo sistema energético.

For its part, the potential of the FRE is the virtual fuel that makes the generation possible, its quantity and quality depends on the amount of energy that can be delivered to the grid. Solar radiation and the wind classify as renewable sources that present a less homogeneous behavior, so that the study and daily, hourly and monthly evaluation of the behavior of solar radiation and wind, is an important activity to be able to carry out the anticipated studies, Of penetration of these renewable sources to the electrical network.

Like other countries, Cuba is focused on finding energy-efficient solutions, so it looks for ways to adjust the satisfaction of increased demand with FRE, in areas where fuels can be substituted [5] with the use of Clean energy sources. The success of this policy may require a process of study and evaluation of the potential of the FRE in the areas of interest.

Solar energy in Cuba has values ranging from $5.2 \mathrm{kWh} / \mathrm{m} 2$ daily in the west to $6.2 \mathrm{kWh} / \mathrm{m} 2$ day in the eastern region, which means that throughout the territory energy productivity does not Provide the same results and therefore the levels of penetration in the network are not the same. A similar situation happens with the wind potential, which does not present the same potential values in the areas selected for its development.

Considering the analysis referred to in the previous paragraph, it demonstrates the importance of the study of the regional or zonal behavior of the FRE. Their results can offer security to the investments made with these energies, guaranteeing a high technical reliability of the system and the provision of energy services.

ECLAC carried out an analysis to achieve the regionalization of energy produced by hydroelectric plants in some countries of Central America and Latin America [6]. When the resource is abundant, different variants of cooperation can be applied; But in the case of RES, regionalization can not only develop between countries, it is necessary to start from territorial analyzes from small areas to large regions and to achieve from smaller scales the cooperation between localities, where the relationship is such that there are potential With certain limitations, or that the conditions for its exploitation do not exist. There must be a compromise between the transmission and distribution and the losses incurred since it does not make sense to transmit to lose.

Until the beginning of 2012 in Cuba, the more than ten thousand photovoltaic applications that had been installed were based on small autonomous systems, designed to guarantee the service in activities of social impact in isolated areas, that did not count on the electric service. Only six small experimental systems connected to the electricity grid were installed in the Pinar del Río, Granma and Santiago de Cuba Provinces with a system in each and three in the province of Havana.

Given the size of the facilities, their unit cost and the speed with which the systems were introduced, studies were not a priority to determine the feasibility of introducing the 
technologies, although in practice they served as experience in the study of Behavior of these applications in the national territory, especially in the eastern and central regions of the country, where most facilities are concentrated.

But when it comes to materializing a definite political will to spread throughout the country, a large group of photovoltaic power plants connected to the grid, with nominal costs per unit of generation amounting to tens and sometimes millions of dollars, implying a commitment of consideration for the use of space and that will gradually have an increasingly important technical impact in the Electroenergetic System (SEN), which is why it is necessary to deepen in the studies of integral feasibility, as a way to achieve security in investments, Technical reliability of the systems and an adequate management that allows the economic recovery of the investments.

The study proposes an analysis based on the division of the country into regions, provinces, municipalities, and localities, assessing the behavior of demand and available potentials. In the particular case of the province of Havana and of the Municipality San Luis in the province of Santiago de Cuba, the solutions must point towards sustainable development.

\section{Research Method}

The Geographic Information System (GIS) is used to carry out the analysis at the local level and to carry out the evaluation of the renewable potential, in cartographic in 1: 100000 and 50: 000. The results of the renewable potential carried out in Santiago de Cuba province and the inventory of renewable energy installations in that territory were studied, as well as the electrification proposal made in the electrical planning [7], where the study of San Luis and the pre-feasibility studies, evaluating the behavior of solar radiation for the introduction of technologies that take advantage of this renewable source. The results of studies related to land use were used, especially in the province of Havana, the region with the highest demand and few areas available for investment.

\section{Results and Analysis}

The realization of the feasibility studies should give answers to a diverse group of technical requirements, requiring the development of methodologies that have the capacity to approach the problems from a multicriterial perspective, that is to say, to be able to define in parallel form a group of exigencies that come from Various disciplines of science, as they turn out; Spatial planning for the use of space, physics for the evaluation of solar radiation, meteorology for the analysis of the behavior of climatic variables, energy for the electrical design of the plant and studies of penetration to the network, The environmental science group to assess impacts related to their areas of action, sociology to evaluate and define the social impacts caused by the introduction of technology, among others.

It can be seen that these demands converge in a complex process of work, which is not related to the simple character with which the introduction of renewable technologies has traditionally been identified. It is a process that must be developed in a dynamic and coordinated way and for this a system of work based on a multicriteria philosophy must be envisaged, where the information of the scientific branches involved can flow in a parallel and organized way, directed to the successful achievement of the project and the safe execution of investments.

\subsection{Havana}

Havana is the province with the highest demand for energy. It is the capital of the country, constituting the largest city in the Caribbean and where approximately 2.2 million inhabitants are concentrated, but in turn, it is relatively small from the territorial point of view. One of the problems faced today is the search for solutions aimed at the introduction of renewable technologies, to promote the fuel savings that today is made to satisfy the energy demand. It has been initially considered that the solution to this problem must be carried through the use of

Gamez, M. R., Perez, A. V., Sera, A. S., \& Ronquillo, Z. M. (2017). Renewable energy sources and local development. International Journal of Social Sciences and Humanities, 1(2), 10-19. 
photovoltaic systems connected to the grid and within this modality, prioritize the installation of the systems in places close to the loads and installed on the roofs.

The use of the soils of the province, are compromised in a high percentage of the residential areas of the people and other purposes and public activities, however, the photovoltaic technology offers great possibilities of being inserted in the urban context, basically taking advantage of the surfaces Horizontal and vertical of the buildings, as well as solar waste and other spaces that do not present an immediate use.

The systems connected to the network have the advantage of being able to be installed directly to the load, which can reduce the losses by transportation and distribution experienced by the centralized system.

\subsection{Evaluation of the incident solar potential in the province}

The basic objective of the investments based on photovoltaic systems connected to the grid lies in the contribution of clean energy to the electrical system to reduce fossil fuel consumption. If solar radiation is considered to be the fuel of these systems, then we have to define that the better the solar radiation, the greater the energy input and the greater the amount of fuel saved. The previous analysis implies that the evaluation of the solar potential is the starting point of the project.

During the works developed in the province of Havana, the solar potential was evaluated and, in parallel, the availability of space for the introduction of photovoltaic technologies was evaluated.

In the large photovoltaic power plants connected to the distribution network, new transformers are installed and sections of electric lines are constructed to evacuate the energy.

In the province under study there are three DGD diesel generator sets, in this case, the areas close to them can be studied, with the aim of taking advantage of the infrastructure of the substation and thereby reducing investment costs, Run at peak times during the day, so it is necessary to know the availability of solar radiation, being able to supply the generation of these installations using fossil fuel.

Considering the previously mentioned elements, in this province the methodology developed in the proposal of the Geoportal of energy [9] was applied, as well as works done for the management of the information in the distributed generation [10] and other investigations related to the territorial organization from studies of solar potential [11].

The values obtained from this analysis are shown in Table 1, as shown by the information available in the areas near the diesel power stations. This is done by managing the geographic information system of renewable energy sources SIG, taking into account the availability of space and the value of solar radiation that affects each $\mathrm{m}^{2}$. With this data, it was possible to estimate the possible photovoltaic power to be installed next to these diesel power plants, the annual average specific productivity per $\mathrm{kWp}$ installed from the incident solar potential, the estimated energy productivity in one year for each installed $\mathrm{kWp}$ and Oil savings estimated at one year for each installed $\mathrm{kWp}$.

Table 1. Calculations of the available areas, the energy that can be generated by each $\mathrm{kWp}$ installed and the estimated saving of oil

\begin{tabular}{lcccccc}
\hline $\begin{array}{l}\text { Power energy } \\
\text { generation }\end{array}$ & $\begin{array}{c}\mathrm{Ad} \\
(\mathrm{ha})\end{array}$ & $\begin{array}{c}\text { Ppi } \\
(\mathrm{kWp})\end{array}$ & $\begin{array}{c}\text { Hip } \\
\left(\mathrm{kWh} / \mathrm{m}^{2} \mathrm{día}\right)\end{array}$ & $\begin{array}{c}\text { Pe } \\
(\mathrm{kWh} / \mathrm{kWp} \\
\mathrm{día})\end{array}$ & $\begin{array}{c}\mathrm{PE} \\
(\mathrm{kWh} / \mathrm{kWp})\end{array}$ & $\begin{array}{c}\text { Cc } \\
(\mathrm{Ton} / \mathrm{kWp} \\
\text { año })\end{array}$ \\
\hline $\begin{array}{l}\text { Diesel Battery } \\
\begin{array}{l}\text { Rín Verde } \\
\text { Diesel Battery }\end{array}\end{array}$ & $\mathbf{1 , 2}$ & $\mathbf{8 5 7}$ & $\mathbf{5 , 5 4}$ & $\mathbf{4 , 5 3}$ & $\mathbf{1 6 5 3}$ & $\mathbf{0 , 4 3}$ \\
$\begin{array}{l}\text { Berroa } \\
\begin{array}{l}\text { Diesel Battery } \\
\text { Guanabo }\end{array}\end{array}$ & $\mathbf{0 , 8}$ & $\mathbf{5 7 1}$ & $\mathbf{5 , 2 9}$ & $\mathbf{4 , 3 3}$ & $\mathbf{1 5 8 0}$ & $\mathbf{0 , 4}$ \\
\hline
\end{tabular}


The estimated power to be installed (Ppi) was calculated by equation (1).

$$
P p i=\frac{A d}{A n}
$$

Where:

$\mathrm{Ppi} \rightarrow$ Estimated power to install $(\mathrm{kWp})$

An $\rightarrow$ Area needed to install $(\mathrm{kWp} / \mathrm{m} 2)$

$\mathrm{Ad} \rightarrow$ Available area calculated by the GIS $\left(\mathrm{m}^{2}\right)$

Based on the value of incident solar radiation at sites close to diesel power plants, it was possible to calculate the annual average specific productivity, that is, the amount of energy that can be generated in one day for each installed kWp of photovoltaic, by means of the equation (2).

$$
P e=(H p i \cdot A c \cdot d) \cdot \eta t \cdot \eta c
$$

Donde:

$\mathrm{Pe} \rightarrow$ Specific productivity $(\mathrm{kWh} / \mathrm{kWp})$

$\mathrm{Hpi} \rightarrow$ Solar radiation on the inclined plane $(\mathrm{kWh} / \mathrm{m} 2$ day)

Ac $\rightarrow$ Area of cell collection $(6,4 \mathrm{~m} 2 / \mathrm{kWp})$

$\mathrm{d} \rightarrow \quad$ Generation time of the photovoltaic plan (1/day)

$\eta t \rightarrow$ Nominal technical efficiency of the modules $(14,2 / 100$ For crystalline silicon marketed in Cuba)

$\eta c \rightarrow$ Efficiency of capture of the radiation by the photovoltaic cells (90/100 in the environmental conditions of Cuba)

Knowing by means of the indicator of the specific productivity was realized in calculation of the estimated energy productivity for a year by $1 \mathrm{kWp}$ installed, by equation (3)

$$
P E=P e \cdot A g
$$

Where:

$\mathrm{PE} \rightarrow$ Energy Productivity $(\mathrm{kWh} / \mathrm{kWp})$

$\mathrm{Pe} \rightarrow$ Specific productivity $(\mathrm{kWh} / \mathrm{kWp})$

$\mathrm{Ag} \rightarrow$ Year of generation (365)

Considering the data of the energy productivity, it was possible to estimate the fuel saving for one year per $1 \mathrm{kWp}$ installed, by equation (4).

$$
C c=P E \cdot I c
$$

Where:

$\mathrm{Cc} \rightarrow$ Fuel consumption (ton $/ \mathrm{kWp})$

$\mathrm{Ic} \rightarrow$ Consumption index (ton $/ \mathrm{kWh}$ )

\subsection{City San Luis}

In the case of the San Luis municipality of Santiago de Cuba province, the development of a methodology similar to that used in the province of La Habana is recommended; but aimed at achieving other objectives of management of renewable sources. The geographical territory of the municipality is shared between a mountainous relief and the plains of the triangle Palma, Mella San Luis. The major conflicts of energy supply are confronted in the mountainous area,

Gamez, M. R., Perez, A. V., Sera, A. S., \& Ronquillo, Z. M. (2017). Renewable energy sources and local development. International Journal of Social Sciences and Humanities, 1(2), 10-19.

https://doi.org/10.29332/ijssh.v1n2.31 
where the network of the electricity system does not reach and the service is provided to rural dwellings for a time of 4 hours in the night time, based on the operation of generators that work with fossil fuel. The facilities are located in isolated areas of very difficult access, where transfer of fuel is difficult, but where there are free soils and renewable potential for their use, in 2010 they had consumed 5.7 million liters of diesel fuel to generate 19.62 MWh with a consumption index of $244 \mathrm{~g} / \mathrm{kWh}$, to favor a population of 177 inhabitants [5].

The proposal is basically based on the use of indigenous renewable resources, to meet demand 24 hours a day. In this case, the regionalization can be valued from another point of view, first because unlike the province of Havana, there is a geographic space available for investment; In addition to the presence of different renewable potential that can solve the problems of demand.

The use of endogenous renewable sources can allow the supply of energy by increasing the number of hours of service, improving the quality of life of people.

The proposal will help replace the use of conventional fuels with local solutions, with less economic and environmental impact, while improving the quality of life of society. The renewable potential of the municipality was studied, where different alternatives were proposed to solve the demands of each of the communities that today use generators, for example, use of the wind potential at 20 meters high, solar potential, hydraulic potential and biomass potential.

The main difficulties of electrification are found in the mountainous areas of San Luis municipality where it concentrates the main energy problems, but there is renewable potential that can be used in different ways, in order to solve the energy problems that the territory has.

These potentials can be used to carry out the replacements of conventional technology, valuing isolated systems that satisfy in each case the necessary demand. In this region there is another potential of interest that can be studied in depth, such as coffee residues, agriculture, animal origin and sugar production, which could undoubtedly be used in local development, improving the quality of life of People living in these isolated areas.

Regionalization can be observed in a macro format as or with a format of local development, but both aimed at finding energy solutions with renewable resources, which provide solutions in accordance with the characteristics and needs of society.

This study shows the possibility of implementing programs that respond to the energy needs and characteristics of the region, for similar cases the energy use should be aimed at solving the problems according to the conditions and characteristics of the territories. Although the availability of many of these sources is plentiful and their real economic potential is considerable, their contribution is aimed at increasing the penetration of renewable sources from the local level in the future.

The use of renewable sources can contribute to reduce dependence on energy imports and increase security of supply, and can develop energy-efficient regions, improving the quality of life of each site according to its characteristics; the introduction of renewable energy sources can constitute a key feature of regional development, achieving social and economic cohesion from local development.

With the results obtained it can be stated that energy regionalization can be developed at different territorial levels, starting from the specific conditions of each locality or area, where indigenous energy resources are included and where there is a demand to supply.

\section{Conclusion}

Two examples are shown related to zones that present differences in their geography and population density; But with similar energy needs in terms of reducing fossil fuel consumption and where the availability of space for the use of renewable sources, offers real possibilities to apply solutions, demonstrating the versatility of the methodology applied for the study in different regions and different Scales of development. The results obtained were managed by the GIS, demonstrating the ability of these systems to manage renewable energy resources, in order to provide regional solutions in different environments of demand, population density and social development. 


\section{Acknowledgement}

The authors thank the editor for this paper to be published online and printed in ScienceScholar Publishing.

\section{References}

1. Adetunji, A. T., Adetunji, A. V., Adeleke, E. O., \& Madubuike, S. C. (2017). Deregulation: The Effect of Market-led Approach to Nigerian Universities Management. International Journal of Social Sciences and Humanities (IJSSH), 1(1), 1-8.

2. Amerta, I. M. S. (2017). The Role of Tourism Stakeholders at Jasri Tourism Village Development, Karangasem Regency. International Journal of Social Sciences and Humanities (IJSSH), 1(2), 20-28.

3. Astawa, I. N., Mantra, I. B. N., \& Widiastuti, I. A. M. S. (2017). Developing Communicative English Language Tests for Tourism Vocational High School Students. International Journal of Social Sciences and Humanities (IJSSH), 1(2), 58-64.

4. Basak, A., \& Khanna, K. (2017). A Study on the Selection Criteria of Different Hotels of Delhi NCR in Accordance to the HR Policies and Market Trends. International Journal of Social Sciences and Humanities (IJSSH), 1(1), 27-38.

5. Billaiya, R., Malaiya, S., \& Parihar, K. S. (2017). Impact of Socio Economic Trends on Students in Quality Education System. International Journal of Social Sciences and Humanities (IJSSH), $1(1), 16-20$.

6. C. Tiba, et al., A GIS-based decision support tool for renewable energy management and planning in semi-arid rural environments of northeast of Brazil. Elsevier, 2010. 35, Renewable Energy: p. 2921-2932.

7. Cedeño, M. L. D., Arteaga, M. G. D., Pérez, A. V., \& Arteaga, M. L. D. (2017). Regulatory Framework for Renewable Energy Sources in Ecuador Case Study Province of Manabí. International Journal of Social Sciences and Humanities (IJSSH), 1(2), 29-42.

8. CEPAL, Istmo centroamericano: LAs fuentes renobales de eenrgía y el cumplimiento de la estrategía 2020. Comisión Económica para América Latina y el Caribe (CEPAL), Sede Subregional en México, 2009. LC/MEX/L953.

9. CONACYT, Energías sustentables en América Latina y el Caribe: Potencial para el futuro. Oficina Regional para América Latina y El Caribe, 2010. 3(ISBN 978-0-930357-79-5): p. www.icsu-lac.org.

10.Gámez, M. R., Pérez, A. V., Será, A. S., \& Ronquillo, Z. M. (2017). Renewable Energy Sources and Local Development. International Journal of Social Sciences and Humanities (IJSSH), 1(2), 1019.

11.Ghosh, C. (2017). A Study on-Evaluating Marketing Strategies Adopted by Home Appliance for Economic Development in India. International Journal of Social Sciences and Humanities (IJSSH), 1(1), 9-15.

12.Inaurys Pérez, María Rodríguez, and A. Vázquez, Gestión de la información de la generación distribuida en Cuba con un sistema de información geográfica. Resúmenes Convención Científica de Ingeniería y arquitectura. ISBN: 978-959-31-1. Diciembre 2010.

13. José A. Meade, C.P. and M.G.B.y. otros, Estrategia nacional para la transición energética y el aprovechamiento sustentable de la energía. Secretaria de energía., 2011.

14. Maba, W. (2017). Teacher's Perception on the Implementation of the Assessment Process in 2013 Curriculum. International Journal of Social Sciences and Humanities (IJSSH), 1(2), 1-9.

Gamez, M. R., Perez, A. V., Sera, A. S., \& Ronquillo, Z. M. (2017). Renewable energy sources and local development. International Journal of Social Sciences and Humanities, 1(2), 10-19.

https://doi.org/10.29332/ijssh.v1n2.31 
15.Maba, W., \& Mantra, I. B. N. (2017). An Analysis of Assessment Models Employed by The Indonesian Elementary School Teachers. International Journal of Social Sciences and Humanities (IJSSH), 1(1), 39-45.

16. María Rodríguez, et al., Ordenamiento territorial de los sistemas de energías renovables a partir de los análisis de la radiación solar en Cuba. Rev. Ecosolar, ISBN: 1028-6004. RNPS: 2220

17. María Rodríguez, et al., Sistemas fotovoltaicos y la ordenación del territorio. En fase de revisión para publicar en Rev. Energética., 2013.

18. Mark Z. Jacobson and M.A. Delucchi, Providing all global energy with wind, water, and solar power, PartI: Technologies, energy resources, quantities and areas of infrastructure, and materials. Elsevier, 2011. Energy Policy 39.

19. Rodríguez, M., Aplicación de los Sistemas de información geográfica en el ordenamiento territorial y la planeación de las fuentes renovables de energía en el municipio de Guamá (Cuba). Informes Técnicos CIEMAT, ISSN: 1135-940, 2009. NIPO: 471-09-059-2. 2009.

20. Rodríguez, M., La ordenación y la planificación de las fuentes renovables de energía en la isla de Cuba desde una perspectiva territorial. Estudio de caso en el municipio de guama a partir de un geoportal. Madrid: CIEMAT; 2012. ISBN 978-84-7834-689-9. 2012.

21.Suparsa, I. N., Mantra, I. B. N., \& Widiastuti, I. A. M. S. (2017). Developing Learning Methods of Indonesian as a Foreign Language. International Journal of Social Sciences and Humanities (IJSSH), 1(2), 51-57.

22.Suryasa, I. W., Prayoga, I. G. P. A., \& Werdistira, I. W. A. (2017). An Analysis of Students' Motivation Toward English Learning As Second Language Among Students In Pritchard English Academy (PEACE). International Journal of Social Sciences and Humanities (IJSSH), 1(2), 43-50.

23.Zoila Millet, María Rodríguez, and R.E. A., Propuesta de sustitución de la energía generada con un grupo electrógeno por energía renovable en la comunidad de Pinar Redondo, del municipio de San Luis. Julio-Septiembre 2010. ISBN: 1026_6004. Ecosolar, 2010. 


\section{Biography of Authors}

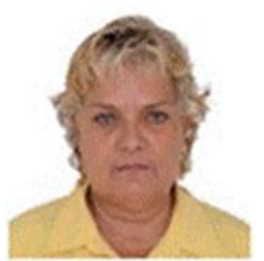

Doctor in Science, professor of the Faculty of Mathematical, Physical, and Chemical Sciences, with several scientific publications participation in international congresses. Works on research projects on sustainable local development, renewable sources

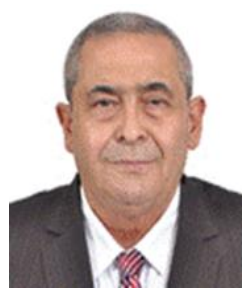

Master, Professor of the Faculty of Mathematical Sciences, Physics, and Chemistry, currently participates in the doctoral program in local development at the University of Alicante, Spain with several scientific publications participation in international conferences. Works on research projects on sustainable local development, renewable sources, and the environment

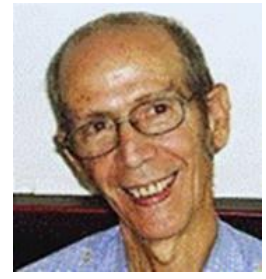

Doctor in Sciences, professor of the Centro de Estudio de Tecnologias Energéticas Renovables de la Universidad Tecnológica de la Habana, Cujae, with several scientific publications participation in international congresses.

Works on research projects on sustainable local development, renewable sources, and the environment

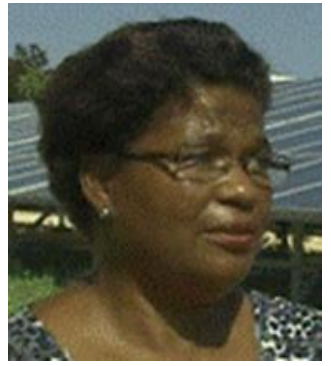

Master in renewable energy, director of the photovoltaic solar energy program of the electricity company of Santiago de Cuba, with several scientific publications participating in international conferences. Works on research projects on sustainable local development, renewable sources, and the environment

Gamez, M. R., Perez, A. V., Sera, A. S., \& Ronquillo, Z. M. (2017). Renewable energy sources and local development. International Journal of Social Sciences and Humanities, 1(2), 10-19. 